\title{
MICROELEMENTAL ANALYSIS OF RICE (ORYZA SATIVA) USING ENERGY DISPERSIVE X-RAY SPECTROSCOPIC (EDXRF) TECHNIQUE
}

\author{
V. K. Rewatkar, A. A. Saoji and K. G. Rewatkar \\ Shri. Dnyanesh Mahavidyalaya, Nawargaon, Chandrapur, (M.S.) India \\ Corresponding author Email : kgrewatkar@gmail.com
}

\begin{abstract}
:
Rice (Oryza sativa) is one of the most important cereal crop. Nearly half of the world"s population depends on this cereal for their daily diet. India has world"s largest area with 39.6

million hectares. There has been increasing interest in chemical speciation of element in recent years which can be attributed to the great alteration in the chemical and the biological properties of the elements depending on their oxidation state, the type of the chemical bonds etc. Applicability of Energy Dispersive X-Ray Fluorescence,(EDXRF) technique for trace elements in rice grains from different fields of the region was demonstrated. To investigate any possible contamination in the grinding procedure or loss of some elements due to the drying process samples were analyzed by total reflection X-ray fluorescence technique. Some microelements are known to be essential for growth of human physique such as $\mathrm{C}, \mathrm{H}, \mathrm{O}, \mathrm{N}, \mathrm{S}$, $\mathrm{Ca}, \mathrm{P}, \mathrm{K}, \mathrm{Na}, \mathrm{Cl}, \mathrm{Mn}, \mathrm{Ti}, \mathrm{Mg}, \mathrm{Cu}, \mathrm{Fe}, \mathrm{Ni}, \mathrm{Si}$ and $\mathrm{Zn}$ totaling to twenty six elements(1-4).There are other elements which occur in animal body but are not essential. They acquired in the body as environmental contamination (5) due to excess use of chemical fertilizers and pesticides on food crops. These fertilizers and pesticides produce an increase in toxic elemental concentration at micro level in Rice plant parts and hence in grains due to absorption of these chemicals. The work being presented here includes micro elemental analysis of grains of some rice varieties. Concentration of metals like $\mathrm{K}, \mathrm{Ca}, \mathrm{Mn}, \mathrm{Mg}, \mathrm{Fe}, \mathrm{Al}, \mathrm{Ti}, \mathrm{P}, \mathrm{Na}, \mathrm{Zn}, \mathrm{Cu}$, and $\mathrm{Si}$ are studied using (EDXRD) techniques
\end{abstract}

\section{Keywords:}

Microelements, EDXRF, rice grains, proliferation, pesticides

\section{Introduction:}

Rice (Oryza sativa) is one of the most important cereal crop. Nearly half of the world"s population depends on this cereal for their daily diet. India has world"s largest area with 39.6 million hectares. There has been increasing interest in chemical speciation of element in recent years which can be attributed to the great alteration in the chemical and the biological properties of the elements 
depending on their oxidation state, the type of the chemical bonds etc.applicability of Energy Dispersive X-Ray Fluorescence,(EDXRF) technique for trace elements in rice grains from different fields of the region was demonstrated. To investigate any possible contamination in the grinding procedure or loss of some elements due to the drying process samples were analyzed by total reflection X-ray fluorescence technique. Some microelements are known to be essential for growth of human physique such as $\mathrm{C}, \mathrm{H}, \mathrm{O}, \mathrm{N}, \mathrm{S}, \mathrm{Ca}, \mathrm{P}, \mathrm{K}, \mathrm{Na}, \mathrm{Cl}, \mathrm{Mn}, \mathrm{Ti}, \mathrm{Mg}, \mathrm{Cu}, \mathrm{Fe}, \mathrm{Ni}$, Si and Zn totaling to twenty six elements [1-4]. There are other elements which occur in animal body but are not essential. They acquired in the body as environmental contamination [5] due to excess use of chemical fertilizers and pesticides on food crops. These fertilizers and pesticides produce an increase in toxic elemental concentration at micro level in Rice plant parts and hence in grains due to absorption of these chemicals. The work being presented here includes micro elemental analysis of grains of some rice varieties. Concentration of metals like K, $\mathrm{Ca}, \mathrm{Mn}, \mathrm{Mg}, \mathrm{Fe}$,

$\mathrm{Al}, \mathrm{Ti}, \mathrm{P}, \mathrm{Na}, \mathrm{Zn}, \mathrm{Cu}$, and $\mathrm{Si}$ are tudied using (EsDXRD) techniques

\section{Material and Method:}

EXPERIMENTAL: All samples were collected from different fields of Eastern Vidarbh zone of Maharashtra around 5.20g of rice were collected from different fields and stored in polyethene bags. These grains were dried for $24 \mathrm{hr}$ in an oven at $350 \mathrm{C}$ in a glass beaker without any washing. Then the samples were powdered in an agate mortar with a particle size $20-100 \mu \mathrm{m}$. Pallet of $2.54 \mathrm{~cm}$ diameter were prepared using hydraulic press at a pressure of 10 tones $/ \mathrm{cm}$. A minimum of 3 pallets of each sample were made to reduce the error in the analysis. Boric acid powder was used as plasticizer. The energy dispersive Xray fluorescence spectrometer consists of a tungsten X-ray tube and a molybdenum secondary target. The X-ray generator was operated at $20 \mathrm{KV}$ and $50 \mathrm{~mA}$. A characteristic radiation was detected using argon flow scintillation counter over the range of $0-1100 \mathrm{C}$ with $6 \mu \mathrm{m}$ polypropylene window. The data 
was analyzed using Uni Quant -2 package and evaluate using the fundamental parameter method as well described in the literature (6-7).

\section{Result and Discussion:}

To establish reproducibility of the instrument technique six pellets of each sample were analyzed. The results of the analysis in $\mu g-1$ (dry weight) of 35 samples were collected from different fields of the region under study (8). The EDXRF analysis shows that various microelements are existing in different micro level in all reported varieties of rice. In particular the percentage of NKP in comparison to other microelements is due to excessive use of synthetic fertilizer (8-9) elements such as iron, zinc ,manganese and copper are detected in lower concentration which lead to the fact that these elements from insoluble inorganic legends by reacting with other solvents existing in soil.

Most of the rice varieties are grown in the warm and humid weather unfortunately tropical condition also favour the proliferation of insects on rice plants. Chemicals pesticides and insecticides are mixed in field water or spread on the plants during cultivation which get distributed throughout the tissue .The elements viz $\mathrm{Mg}, \mathrm{Al}, \mathrm{Ti}$, and $\mathrm{Ni}$ are residues of pesticides and insecticides absorbed by the plant parts like rice grains in various micro percents which after consumption may be a hazard to human physique

\section{Conclusion:}

The elements viz $\mathrm{Mg}, \mathrm{Al}, \mathrm{Ti}$, and $\mathrm{Ni}$ are residues of pesticides and insecticides absorbed by the plant parts like rice grains in various micro percents which after consumption may be a hazard to human physique.

\section{Reference:}

H.J.M. Bowen, trace elements in biochemistry, Academic press, New York (1996) 
V.Valkovic, trace elements analysis, tayrov and Francis, London (1979)

Analysis of Biological Material for trace element using X-ray spectroscopy ,CRC Press ,Boca Raton, FL(1980).

P. Bratter and P. Schramel, trace element analysis and biology, Walter de Gruyter, Berlin (1980)

Madan Lal and R.K.Choudhary, Indian J. of Physics 65B , 30

(1991) J.Bohman and V.Isakson, X-ray spectom ,20.305 (1989)

A. Rindby, X-ray spectrom -18,113 (1989)

S.V. Rao and Krishna Rao Andra Agr. J. 9.255 (1961)

Rewatkar et al. Asian J. chem. Vol.13.No.1 206-210, (2001) 